\title{
A EXPRESSÃO DO INDIVIDUALISMO, DO COLETIVISMO E DO COMUNITÁRIO NA OBRA JUBIABÁ(JORGE AMADO).
}

\section{SILVA, Leila Barros dos Santos ${ }^{1}$; OLIVEIRA, Humberto Luiz Lima de ${ }^{2}$}

\author{
${ }^{1}$ Bolsista Fapesb (Graduanda em Letras com Espanhol/UEFS) e-mail: \\ $\underline{\text { bjpjleticia@hotmail.com.br }}$ \\ ${ }^{1}$ Orientador, Doutor em Literatura Comparada, ( Departamento De Letras E Artes,UEFS ), e-mail: \\ humbert_oliveira@uefs.br
}

PALAVRAS-CHAVES: Jorge Amado; individualismo; coletivismo; comunitário;

Este Resumo faz parte do projeto de pesquisa: Assim caminha a humanidade? Revisitando utopias; do individualismo; do coletivismo e do comunitário, que investiga o individual, coletivo comunitário na obra do escritor Baiano Jorge Amado, participando da construção do sujeito pós-moderno. A pesquisa aborda as temáticas dos valores individuais, coletivos e comunitários na sociedade brasileira. Este estudo tem como base a obra jubiabá (1935) do escritor Jorge Amado, que conta de forma séria a expressão do individual, do coletivismo e do comunitário, na trajetória do protagonista Antônio Balduíno, o primeiro herói negro da literatura brasileiro. O Autornarrador assume, durante o desenvolvimento narrativo, uma feição revolucionária, ao passar da rebeldia para quando chefiava as quadrinhas de um grupo de molecotes que vagabundavam pelo Morro, retratando a vida em comunidade e o coletivo. Ainda assim, se tornou o homem livre que rejeita todas as profissões e prova diversas experiências de vida chegando a ser líder grevista.

\section{MATERIAIS E MÉTODOS}

Para o andamento dessa pesquisa, inicialmente, foram empregadas técnicas de pesquisa documental e bibliográfica com o objetivo de construir o conteúdo a ser analisado, de ampliação do vocabulário e da necessária compreensão de noções e conceitos de múltiplas áreas do conhecimento como, literatura, individualismo, sociedade, coletivismo, liberdade, comparativismo, sociedade, história brasileira, sem o que não teríamos conseguido realizar as leituras adequadamente. Em seguida, foram realizados estudos sistemáticos, discussões coletivas, em grupos de estudo, participação em curso de extensão e leitura de textos.

\section{RESULTADOS E/OU DISCUSSÃO}

Com método de análise da obra, tomamos como base os métodos da Literatura comparada na medida em que esta plataforma conceitual permite estabelecer articulações entre obras e gêneros a partir de um fio condutor comum, no caso a temática, como nos lembra (MACHADO e PAGEAUX: 1989). Por tema recorrente na narrativa Jubiabá(1935), de jorge Amado, no romance tentará promover a ascensão dos interesses da classe proletária, como que uma apropriação do modelo burguês do 
romance servindo á luta contra a lógica social da própria burguesa. No entanto, Antônio Balduíno ficava de cima do morro vendo a fila de luzes que era a cidade lá embaixo, onde tinha uma admiração individual pela cidade, por isso perdia a horas do jantar e das brincadeiras para contemplar esse espaço urbano. Assim, a sociedade moldando a individualidade seus membros e os indivíduos formando a sociedade a partir de suas ações individuais (BAUMANN.p.62). Observando-se o nível crescente do individualismo e da indiferença em relação de indivíduos de antigas comunidades, pode -se pensar que a civilização contemporânea pressuponha o apagamento de laços de solidariedade. Porém, em se tratando de literatura comparada, com acesso á leitura de textos, pretendo identificar em diferente sociedade, a solução narrativa que aponta seja para o abandono das comunidade, seja para a recusa ao coletivismo, seja para adesão do individualismo como norma de conduta, meta social a ser atingida por todos os indivíduos. Logo, Baldo desde cedo observava a vida dos trabalhadores e operários escravizados e se imaginava homem feito naquela luta diária, mas ainda, passou a participar das lutas dos operários e perceber que o povo podia deixar de ser escravizados lutando pelos direitos trabalhistas na sociedade.

\section{CONSIDERAÇÕES FINAIS}

A narrativa do romance, é decorrente a concepção de mundo do escritor, aponta, para o peso esmagador do individualismo que leva homens e mulheres a padecerem de sofrimentos que poderiam ser evitados ou minimizados se outras fossem as formas de viver e pensar. De fato, a sociedade considerada crescente, individualista, a conexão com o comunitário tem sido reduzido ao simples pertencimento do coletivo,onde ocorre um grito distante do bem comum.

\section{REFERÊNCIAS}

AMADO,Jorge,1912-Jubiabá:romance:ilustrações de Carybe-57-tiragem-Rio de janeiro:Record,2000

FISCHER, Ernst. A necessidade da arte. Rio de Janeiro: Guanabara, 2001.

FORGET, Danielle; OLIVEIRA, H.L.L.de. Imagens do Outro: leituras divergentes da alteridade. Feira de Santana: UEFS, 2001.

OLIVEIRA, H.L.L.de. "Leituras de exilados em narrativas literárias". In (org) ADESKY, Jacques d'; SOUZA, Marcos Teixeira de. Afro-Brasil Debates \&Pensamentos. Rio de Janeiro: Cassara, 2015.

OLIVEIRA, H.L.L.de. "Agaguk, a morte e a reinvenção das tradições”.In. (org) HUNTER, Nigel. Vistas diversas. Feira de Santana: UEFS, 2013.

OLIVEIRA, H.L.L.de; SCHEINOWITZ, Celina; LAROCHE, Maximilien. Haiti: 200 anos de distopias, diásporas e utopias americanas. Feira de Santana: 2004.

OLIVEIRA, H.L.L.de; SCHEINOWITZ, Celina. Vozes e imagens da alteridade. Feira de Santana: UEFS, 2003.

RAMOS, Graciliano. Vidas Secas. São Paulo: Martins, 1968.

SAWAIA, Bader. As artimanhas da exclusão.Analise psicossocial e ética da desigualdade social. 12.ed. Petrópolis: Vozes, 2012. 